\title{
ICU-AW の予防を目指す早期からの蛋白栄養と理学療法の介入について
}

\author{
大島 拓 ${ }^{1)}$ ，春山美咲子 ${ }^{2)}$ ，今井正太郎 ${ }^{3)}$ ，古川誠一郎 ${ }^{3)}$, 佐藤 由美 ${ }^{4)}$
}

\begin{abstract}
重症病態から生還する患者が増加する一方で，治療中に身体機能が低下する患者が増えてい る。こうして発症する Intensive care unit acquired weakness（ICU-AW）の予防や治療の手段 として, 早期の栄養療法や理学療法の確立が期待されている。当施設では他職種チームによる 早期栄養療法および早期能動的運動療法プログラムを導入している. 重症度に関係なく早期か ら患者の状態に合わせて強度を調整した理学療法を実施ししている。また，栄養療法ではエネ ルギー・蛋白の投与目標を設定し, 早期から充足させることを目標として段階的に介入を進め てきた。当施設での後方視的検討では早期の蛋白投与により筋肉量の減少が抑えられる可能性 が示唆され，今後は ICU-AW 予防の観点から理学療法，栄養療法をより効果的に活用する方 法の確立が望まれる。
\end{abstract}

ICU-AW, 早期栄養療法, 蛋白栄養, 早期理学療法, 多職種連携

\section{Iはじめに}

重症病態の多くは高度な侵襲を背景として発症し た重要臓器障害を呈し，その制御には原因疾患の治 療が肝要となる。この間, 持続的な生体モニタリン グ下に人工呼吸器や持続的腎代替療法, 心肺補助療 法などの機械的補助に代表される侵襲的治療が必要 となり，治療中の安全性や苦痛緩和の目的で鎮痛剂 や鎮静剤が使用されるケースが多くなる。こうした 重症病態治療の結果として身体障害を残し, 回復に 難渋する症例が後を絶たない ${ }^{1)}$.

こうした重症病態治療後の身体機能の低下を総称 $し て$ intensive care unit acquired weakness (ICU-AW) と呼ぶ. ICU-AW は発症してからでは対応が難し くなることから，その予防対策として栄養療法と理 学療法が同時に適切に行われることが重要だと考え られている. 当施設では早期能動的運動療法プログ ラムを 2006 年ごろより開始し，2018 年からは早期 離床・リハビリテーション加算に対応するため, 多 職種からなるICU内でのリハビリテーション・ チームも編成した。また，2012 年より ICU 内の栄

2019 年 12 月 24 日受付 : 2020 年 4 月 7 日採用決定

千葉大学大学院医学研究院救急集中治療医学 ${ }^{11}$

干260-8677 千葉県千葉市中央区亥鼻 1-8-1

同 医学部附属病院 ICU/CCU 病棟 ${ }^{2)}$

同 医学部附属病院リハビリテーション部 ${ }^{3)}$

同医学部附属病院臨床栄養部 ${ }^{4)}$

発表学会：日本外科代謝栄養学会第 56 回学術集会
養療法を充実させるために多職種からなる栄養チー ムを結成し，さまざまなツールを活用して個々の患 者に対する適切な栄養療法を目指している。本稿で は ICU-AW の解説に引き続き, 当施設での多職種 連携を通じた ICU-AW 予防対策について解説する。

II ICU-Acquired Weakness（AW）のメカニズム 重症病態に伴う身体障害のメカニズムとして多発 神経障害 (critical illness polyneuropathy; CIP) や 骨格筋障害 (critical illness myopathy; CIM)，それ らが混在する critical illness neuromyopathy (CINM) が報告されており ${ }^{2)}$ ，これらが引き起こす身体機能 の低下を総称して ICU-AW と呼んでいる ${ }^{3), 4)}$. ICU-AW の発症には, 重症病態に伴う生体侵襲と 治療に伴う不動化が大きく関わっていると考えられ ており，低栄養状態は ICU-AW の進行を助長する と考えられている.

重症患者では侵襲時のエネルギーとしての利用や 蛋白源として筋組織が利用されるため, 発症後早期 から筋組織が䘫失すると考えられており ${ }^{5)}$, 重症な 症例ほど岥失量が多くなる傾向が示されている ${ }^{6)}$. 結果的に ICU-AW を発症すると人工呼吸器装着期 間, ICU ならびに病院滞在期間が長期化し, 身体 機能の低下が顕著な症例ほど死亡率が高くなる77.

Yende らは, 敗血症患者の生存症例のうち 6 力月後 までに $30 \%$ が死亡し，1/3 が身体機能の障害を残 
表 1a 早期能動的運動療法プログラム (文献 ${ }^{18)}$ より改変)

\begin{tabular}{|c|c|c|c|c|}
\hline 運動強度 & 部位 & 種類 & 内容 & 強度目安 \\
\hline 0 & 四肢 & 他動運動 & & \multirow[t]{5}{*}{ 低強度 } \\
\hline \multirow{2}{*}{1} & 上肢末梢 & \multirow{2}{*}{ 自動介助運動 } & 手指屈伸, 时関節屈伸 & \\
\hline & 下肢末梢 & & 足関節底背屈 & \\
\hline \multirow{2}{*}{2} & 上肢全体 & \multirow{2}{*}{ 自動介助運動 } & 上肢総屈伸 & \\
\hline & \begin{tabular}{|l} 
下肢末梢 \\
\end{tabular} & & 足関節底背屈 & \\
\hline \multirow{2}{*}{3} & 上下肢全体 & \multirow{2}{*}{ 自動介助運動 } & 上下肢総屈伸 & \multirow[t]{8}{*}{ 高強度 } \\
\hline & 体幹 & & 熨部挙上, 頚部屈伸 & \\
\hline \multirow{3}{*}{4} & 上肢全体 & \multirow{2}{*}{ 自動運動 } & 上肢総屈伸 & \\
\hline & 体幹 & & 慰部挙上, 頚部屈伸 & \\
\hline & 下肢全体 & 自動介助運動 & (膝伸展位) 股関節屈伸 & \\
\hline \multirow{3}{*}{5} & 上下肢全体 & 抵抗運動 & 上下肢総屈伸 & \\
\hline & 下肢全体 & \multirow{2}{*}{ 自動運動 } & (膝伸展位) 股関節屈伸 & \\
\hline & 体幹 & & 臂部挙上, 頚部屈伸 & \\
\hline
\end{tabular}

表 $1 b \quad$ 早期離床プロトコル 目標レベル (文献 ${ }^{18)}$ より引用)

\begin{tabular}{|c|c|c|}
\hline \multicolumn{2}{|c|}{ 離床レベル } & 内容 \\
\hline \multirow[t]{2}{*}{$\overline{1^{-}}$} & 1 & 臥位 \\
\hline & 2 & ベッドアップ $45^{\circ}$ 以上 \\
\hline \multirow[t]{2}{*}{$\overline{2-}$} & 1 & 端坐位（介助で 5 分保持） \\
\hline & 2 & 端坐位（自立して 5 分保持) \\
\hline 3 & & 立位 \\
\hline 4 & & 歩行 \\
\hline
\end{tabular}

し，そのうちの半数は 1 年以内に死亡するか, 長期 的に障害を残した状態になることを報告してい る ${ }^{8)}$. 一般的に高齢者に発症した ICU-AWを回復 させることが困難であることは知られているが,

Herridge らの報告によると呼吸不全により人工呼 吸管理を要した若年者で 5 年後でも歩行機能に障害 を残すことを報告しており, 若年者でも回復が遅延 することが示唆される ${ }^{9)}$.

\section{ICU-AW と理学療法}

理学療法は主に ICU-AW の原因となる不動化を 解消することで筋萎縮ならびに筋力の低下を抑制 し, ICU-AW の発症ならびに増悪の抑制につなが ると期待されており，2016年に発行された日本版 敗血症診療ガイドラインの中でも弱く推奨されてい る ${ }^{10)}$. ICU-Aの予防を目指すためには早期に開始 することが望ましいと考えられるが，早期開始の定 義や効果的な予防につながる理学療法の強度は明確 ではなく、今後の研究が待たれるところである。ま た，理学療法には ICU-AW の抑制効果は期待でき るものの, せん妄や精神障害の改善効果はないとす る meta-analysis の報告もある ${ }^{11)}$.

\section{ICU-AW と栄養療法}

低栄養状態は筋組織の䘫失につながり, ICU-AW を助長すると考えられている。したがって ICUAW を予防するための栄養療法は, 必要十分なエネ ルギーと蛋白の投与がポイントとなる。しかし，本 邦に扮ける重症患者に対する栄養投与は十分とはい えず，Higashibeppu らはエネルギー充足率が $10 \%$ 上昇するごとに有意に生命予後が改善することを報 告している ${ }^{12)}$ 。また，高蛋白栄養刘の使用により 1 日体重あたり $1.2 \mathrm{~g}$ 以上の蛋白質を投与すること で，アミノ酸合成の刺激につながることが報告され
ている ${ }^{13)}$.さらに，経腸栄養では不足するエネル ギーと蛋白を経静脈的なブドウ糖とアミノ酸の投与 で補足することにより，筋肉の衰失を抑制できる可 能性が示唆されている ${ }^{14)}$ 。こうした目標を達成する ために，必要エネルギー量の推定は間接熱量測定の 結果を用いることが推奨されているが，必要な蛋白 量については明確な推奨には至っていない。経腸栄 養の場合は可及的速やかな投与が推奨される一方 で，早期からの経静脈的なアミノ酸投与の併用によ り蛋白投与量を充足させることで尿素窒素值が上昇 することや ${ }^{15)}$ ，グルカゴンの産生の促進からさらに 肝内のアミノ酸分解が促進されるとの報告もあ る ${ }^{16)}$ 。また，最近の早期栄養に関するランダム化比 較試験の 2 次解析の結果からは, 早期からのアミノ 酸投与が肝臓や骨格筋に打けるオートファジーを抑 制し, 結果的に肝や筋組織の修復が正常に行われな いことで筋萎縮を助長する可能性も示唆されてい る ${ }^{17)}$. 以上より, 静脈栄養の併用による蛋白投与量 の充足とそのタイミングについては議論が分かれる ところであり，今後の研究が待たれるところであ る。

\section{$\mathrm{V}$ 当施設における早期理学療法導入の試み}

\section{1. 早期能動的運動療法}

当施設では早期から身体機能を維持することを目 標とした独自の能動的運動療法プログラムを策定し 運用している $($ 表 $1 \mathrm{a}){ }^{18)}$ ， 上肢・下肢・体幹の各領 域別に運動強度を 0 から 5 （0２ 2 低強度，3～5 を高強度）までに分類した目標を設定している。ま た，離床レベルにも段階を設けることで（表 1b）， 運動療法と合わせて到達度が評価できる仕組みとし ている ${ }^{18)}$ ，毎朝行われる症例カンファレンスで治療 方針の一環として導入の可否を判断し，安静を要す る患者には他動的運動から導入するが，呼吸・循環 
表 2 ICU 栄養チームによる取り組みの変遷

\begin{tabular}{|c|c|c|c|}
\hline Phase & 時期 & 介入手段 & 栄養療法の目標 \\
\hline 1 & ～2012 年 3 月 & 医師主導の栄養療法 & 主治医判断 \\
\hline 2 & 2012 年 4 月～2013 年 11 月 & $\begin{array}{l}\text { ICU 栄養チーム結成 } \\
\text { 専属管理栄養士の配置 } \\
\text { 栄養療法プロトコル導入 }\end{array}$ & $\begin{array}{l}\text { 早期充足型栄養療法 } \\
\quad \cdot 48 \text { 時間以内の } \mathrm{EN} \text { 開始 } \\
\cdot \text { - EN 開始後 } 72 \text { 時間以内に目標の } 80 \% \text { 充足 } \\
\cdot 7 \text { 日以内に EN 充足困難な場合の静脈栄養 }\end{array}$ \\
\hline 3 & 2013 年 11 月 2016 年 9 月 & 栄養シート導入 & \\
\hline 4 & 2016 年 10 月～ & $\begin{array}{l}\text { EN アルゴリズム導入 } \\
\text { 栄養ラウンド導入 }\end{array}$ & 蛋白投与目標を設定（1.0-1.2 g/kg 体重／日） \\
\hline
\end{tabular}

表 3 抽出症例の背景 : 腸腰筋断面積の変化率の検討 栄養チームの介入段階（Phase）ごとの腸腰 筋断面積を検討した症例の背景. データは平均土標準偏差または中央值（四分位）で表記.

\begin{tabular}{|c|c|c|c|}
\hline Phase & 2 & 3 & 4 \\
\hline $\mathrm{n}$ & 7 & 7 & 8 \\
\hline 年齢（歳） & $68 \pm 7$ & $63 \pm 18$ & $62 \pm 11$ \\
\hline 性別（男：女） & $6: 1$ & $5: 2$ & $4: 4$ \\
\hline BMI & $25 \pm 3$ & $22 \pm 4$ & $25 \pm 5$ \\
\hline NUTRIC Score & $7 \pm 3$ & $8 \pm 1$ & $7 \pm 1$ \\
\hline APACHE II Score & $31 \pm 12$ & $34 \pm 8$ & $30 \pm 5$ \\
\hline SOFA Score & $12 \pm 5$ & $13 \pm 5$ & $11 \pm 4$ \\
\hline IL6 初回值（pg/mL） & $305(20 \sim 99578)$ & $1010(128 \sim 3426)$ & $1090(239 \sim 7944)$ \\
\hline 7 日目エネルギー投与量（kcal/kg/日） & $14(11 \sim 23)$ & $20(19 \sim 29)$ & $24(15 \sim 26)$ \\
\hline エネルギー充足率（％） & $54(44 \sim 92)$ & $79(77 \sim 116)$ & $96(62 \sim 106)$ \\
\hline 7 日目蛋白投与量（kcal/kg/日） & $0.4(0.2 \sim 0.7)$ & $0.5(0.4 \sim 0.6)$ & $0.9(0.7 \sim 1.2)$ \\
\hline 蛋白充足率（\%） & $37(2172)$ & $51(38 \sim 61)$ & $90(73-118)$ \\
\hline ICU 滞在期間（日） & $22 \pm 8$ & $23 \pm 15$ & $26 \pm 18$ \\
\hline 死亡率（\%) & 14 & 43 & 25 \\
\hline
\end{tabular}

動態が安定していれば心血管作動薬や人工補助療法 中であっても能動的運動への移行を図っている。医 師と理学療法士が病態や病勢に応じて毎日のラウン ドで運動強度の目標レベルを設定し，リハビリテー ションシートを利用して看護スタッフをはじめ多職 種で共有できる仕組みとしている。

\section{2. 早期能動的運動療法による離床誘導効果}

早期能動的運動療法プログラムによる離床誘導効 果について，筆者らは 2018 年 1 月から 3 月までの 間に当 ICUに入室し，リハを実施した 70 例の重症 患者で検討した結果を報告している ${ }^{18)}$ 。低強度から 開始してリハ開始 1 週間後の運動が低強度に留まっ た群（低一低強度群, $\mathrm{n}=18$ ) と, 高強度に移行で きた群（低一高強度群, $\mathrm{n}=17$ ) では平均 $\mathrm{APACHE}$ II $(37 \pm 5,34 \pm 6 ;$ n.s. $)$, SOFA score $(11 \pm 3,11$ \pm 3 ; n.s.）に差はなく, 低強度から高強度への運動 療法への移行に初期の重症度は関連がないことが示 唆された ${ }^{18)}$ 。また，高強度に移行できた症例では端 座位まで進む症例が多く，低強度にとどまった群と 比較し生存退院率（76\% vs $50 \%, \mathrm{p}=0.01 ）$ ならび に自宅退院率 $(29 \%$ vs $0 \%, \mathrm{p}=0.01)$ ともに有意 に高かった ${ }^{18)}$ 。以上より，たとえ ICU入室時の重 症度が高い症例でも早期に理学療法を開始すること で実際に高強度プログラムに移行していくことがで
きる症例が存在することが示された。

\section{VI 当施設における早期蛋白栄養導入の試み}

\section{1. 早期栄養療法}

当院のICUでは，2012 年に栄養チームを発足 し，栄養療法プロトコルを策定して効率的な栄養療 法の実践を図っている。栄養チームは医師, 管理栄 養士, 看護師, 理学療法士, 薬剤師, 臨床工学技士 で構成されており, 多職種で個々の患者の栄養療法 を日々検討している ${ }^{19)}$ 。栄養療法プロトコルの実践 のため, 2013 年から栄養管理に必要な情報をわか りやすく収集・共有できる栄養シートを導入し, 2016 年には EN アルゴリムや栄養ラウンドを導入 した（表 2)。ENアルゴリズムとは入室後 48 時間 以内に経管栄養を開始し, 開始後 72 時間で目標投 与量の $80 \%$ 以上の投与を目指す基本の栄養療法プ ロトコルに対し，看護師があらかじめ設定した評価 基準に基づき経腸栄養の継続や増量の可否を評価 し，栄養投与量の充足プランを提案する制度であ る。また，栄養ラウンドでは各患者に必要なエネル ギーと蛋白両方の目標を病態変化に合わせて設定 し，投与量の充足を目指した栄養療法を実践してい る. 

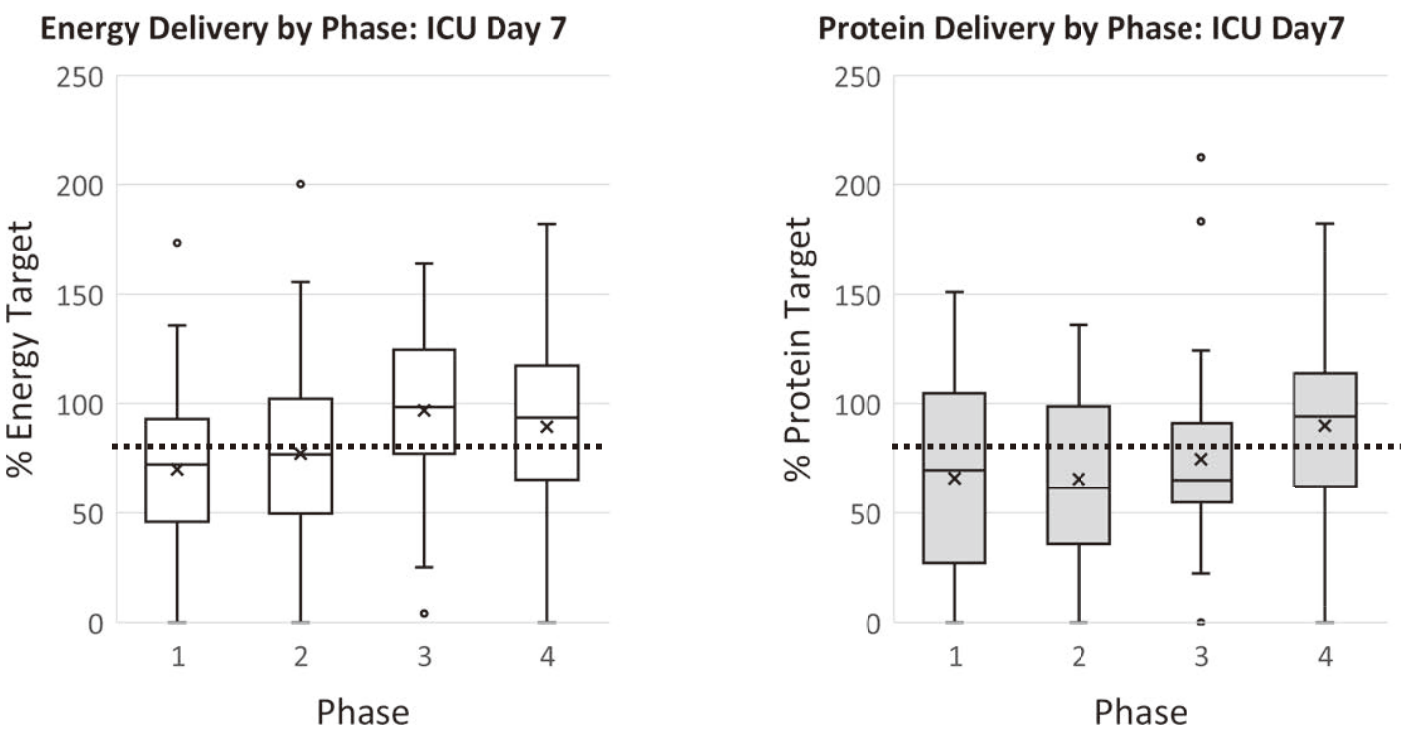

図 1 ICU 入室 7 日目のエネルギー・蛋白充足率

ICU 栄養チームによる介入段階（Phase）ごとのエネルギーおよび蛋白充足量. 栄養プロトコルを 導入したPhase 2 まではエネルギー・蛋白ともに目標投与量を達成できていないが，栄養シートを 導入したPhase3 以降でエネルギーを，ENアルゴリズムや栄養ラウンドを導入した Phase4 では蛋 白投与量も目標投与量の $80 \%$ 以上の投与を実現することができた。（エネルギー投与目標： $25 \mathrm{kcal} /$ $\mathrm{kg}$ (体重)/日 ; 蛋白投与目標 : $1.0 \mathrm{~g} / \mathrm{kg}$ (体重)/日 ; 点線はプロトコル上の目安である目標投与量 の $80 \%$ 充足を示す)

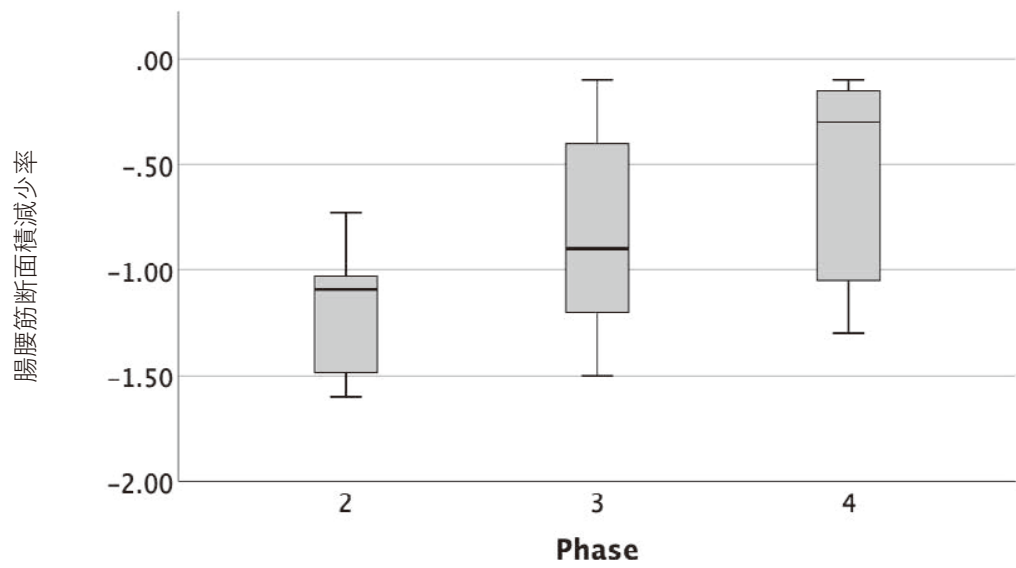

図 2 Phase 2 以降の腸腰筋断面積の変化率

エネルギー・蛋白ともに充足が不十分な Phase 2 からエネルギー投与 量が充足できたPhase3，蛋白も充足できたPhase4に進むにつれ， ICU 入室時から第 7〜 14ICU 病日までの CT で評価する腸腰筋断面積 の減少率は少なくなる傾向にあった。（腸腰筋断面積減少率は腹部 CT の腰椎 L3 高位の腸腰筋断面積を ICU 入室前後 1 日以内の CT と第 7 〜 $21 \mathrm{ICU}$ 病日の CT で評価し, 断面積の差を初回の断面積で除して変 化率を算出したのち，CT 撮像間隔日数で除したもの.)

付表 1 腸腰筋断面積変化率と患者背景因子の相関 患者背景のうち，連続変数であるものと腸腰筋断面積の IICU 病日あた りの変化率について（Psoas delta：腸腰筋断面積の1病日あたりの変化率，IL6_initial：初回 IL-6 血中濃度, Calorie_day7_BW : 第 7 ICU 病日の体重あたりのエネルギー投与量, Protein_day7_BW : 第 7 ICU 病日の体重あたりの蛋 白投与量 ; SPSS Statistics version 26)

\begin{tabular}{|c|c|c|c|c|c|c|c|c|}
\hline \multicolumn{9}{|c|}{ Correlations } \\
\hline & & AGE & BMI & APACHE_II & SOFA & IL6_initial & $\begin{array}{l}\text { Calorie_ } \\
\text { day7_BW }\end{array}$ & $\begin{array}{l}\text { Protein_ } \\
\text { day7_BW }\end{array}$ \\
\hline \multirow{3}{*}{ Psoas_delta } & Pearson Correlation & .027 & .229 & -.064 & -.045 & -.042 & .191 & .332 \\
\hline & Sig. (2-tailed) & .906 & .305 & .777 & .841 & .858 & .394 & .131 \\
\hline & $\mathrm{N}$ & 22 & 22 & 22 & 22 & 21 & 22 & 22 \\
\hline
\end{tabular}




\section{2. 早期栄養療法の効果}

上記の取組みの各段階を多職種チーム結成前 (Phase 1)，プロトコル導入後（Phase 2)，栄養 シート導入後 (Phase 3), 栄養ラウンドと ENアル ゴリズム導入後（Phase 4) の 4 Phaseに分類し, 各Phase の取り組みを開始して 6 力月から 9 力月 後に栄養チームが介入した患者の ICU 入室 7 日目 のエネルギーおよび蛋白充足率の中央值（四分位） を検討したところ, Phase $1(\mathrm{n}=39)$ で $72\left(46^{-}\right.$ 93）\%, $70(27-104) \%$, Phase $2(\mathrm{n}=39)$ で 77 (79-102) \%, 61 (36-99) \%, Phase $3(\mathrm{n}=40)$ で 98 (77-124) \%, 65 (54-91) \%, Phase 4 (29) で 94 （65-117）％，94（62-113）\%であった（図 1). すなわち，栄養プロトコルを導入したPhase 2 まで は 7 日目のエネルギー・蛋白ともに目標投与量を達 成できていないが，栄養シートを導入したPhase 3 以降でエネルギーを，ENアルゴリズムや栄養ラウ ンドを導入したPhase 4 では蛋白投与量も目標投与 量の $80 \%$ 以上の投与を実現することができた。 そ こで Phase 2 以降で ICU 入室前後 1 日以内および 入室後 7 日から 21 日までに腹部 CT が撮影されて いた症例を抽出し, 腰椎 L3 下縁レベルでの腸腰筋 断面積を計測した。抽出した症例の ICU 入室 7 日 目のエネルギーおよび蛋白投与充足率の中央值は Phase $2(\mathrm{n}=7)$ で $54 \%, 37 \%$, Phase $3(\mathrm{n}=7)$ で $79 \%$, 51\%, Phase $4(\mathrm{n}=8)$ で $96 \%, 90 \%$ あった (表 3). 入室時点から入室後の腸腰筋断面積の変化 量を 1 日あたりの変化率 (中央值) として比較した ところ, Phase 2 で-1.1, Phase 3 で-0.9, Phase 4 で-0.3, であり, Phase 2 と 4 の間では有意な差 を認めた（p=0.01, independent t-test, SPSS Statistics ver.26）（図2）。そこで，表 3 に示した背景因 子 (連続変数のみ) と腸腰筋断面積变化率との相関 関係を確認したところ, ICU 入室 7 日目の蛋白投与 量のみが弱い相関（相関係数 $=0.332, \mathrm{p}=0.131$ ）を 示した（付表 1). 以上より, ICU 入室後早期から の栄養投与, 特に蛋白投与が筋肉量の維持に寄与す る可能性が示唆されたが, 症例数の限られた後方視 的な検討では有意な関係性は確認できず，実際に栄 養投与が ICU-AW の予防に与える効果については 改めて前向きな検討の必要性が考えられた。

\section{VII 結語}

ICU-AW の予防には栄養療法と理学療法が大き な要素であることが示されている。当施設でも早期 からの理学療法と栄養療法の充実に力を入れてお り，後方視的な検討では早期からの蛋白投与が筋肉
量の維持に寄与する可能性が示唆された。今後は理 学療法掞よび栄養療法の介入時期や方法, 理学療法 と栄養療法の効果的な組み合わせ方などについて活 発な議論が交わされることが望ましい.

本論文の内容は, 2019 年 7 月 5 日に神戸国際会 議場で開催された第 56 回 日本外科代謝栄養学会学 術集会における「シンポジウム 6 集中治療領域にお ける蛋白投与」で発表されたものである.

\section{文献}

1) Kaukonen KM, Bailey M, Suzuki S et al. : Mortality related to severe sepsis and septic shock among critically ill patients in Australia and New Zealand, 2000-2012. JAMA 311 : 1308-1316, 2014

2) Stevens RD, Marshall SA, Cornblath DR et al. : A framework for diagnosing and classifying intensive care unitacquired weakness. Crit Care Med 37 : S299-308, 2009

3) Kress JP, Hall JB : ICU-acquired weakness and recovery from critical illness. N Engl J Med 370 : 1626-1635, 2004

4) Batt J, dos Santos CC, Cameron JI et al. : Intensive care unit-acquired weakness : clinical phenotypes and molecular mechanisms. Am J Respir Crit Care Med 187 : 238246, 2013

5) Puthucheary ZA, Rawal J, McPhail M et al. : Acute skeletal muscle wasting in critical illness. JAMA $310: 1591-$ 1600, 2013

6) Nakanishi N, Oto J, Tsutsumi R et al. : Upper and lower limb muscle atrophy in critically ill patients : an observational ultrasonography study. Intensive Care Med 44 : 263-264, 2018

7) Hermans G, Van Mechelen H, Clerckx B et al. : Acute outcomes and 1-year mortality of intensive care unit-acquired weakness. A cohort study and propensitymatched analysis. Am J Respir Crit Care Med 190 : 410420, 2014

8) Yende S, Austin S, Rhodes A et al. : Long-Term Quality of Life Among Survivors of Severe Sepsis : Analyses of Two International Trials. Crit Care Med 44 : 1461-1467, 2016

9) Herridge MS, Tansey CM, Matte A et al. : Functional disability 5 years after acute respiratory distress syndrome. N Engl J Med 364 : 1293-1304, 2011

10) Nishida O, Ogura H, Egi M et al. : The Japanese Clinical Practice Guidelines for Management of Sepsis and Septic Shock 2016 (J-SSCG 2016). Acute medicine\&surgery $5: 3-89,2018$

11) Fuke R, Hifumi T, Kondo $Y$ et al. : Early rehabilitation to prevent postintensive care syndrome in patients with critical illness : a systematic review and meta-analysis. BMJ open 8 : e019998, 2018 
12) Higashibeppu N, Sobue K, Heyland DK : Association betseen greater energy intake and lower mortality in critically ill patients in the Japanese ICU. 日本集中治療医学会 誌, 2018

13) Looijaard W, Denneman N, Broens B et al. : Achieving protein targets without energy overfeeding in critically ill patients : A prospective feasibility study. Clin Nutr 38 : 2623-2631, 2019

14) Berger MM, Pantet $\mathrm{O}$, Jacquelin-Ravel $\mathrm{N}$ et al. : Supplemental parenteral nutrition improves immunity with unchanged carbohydrate and protein metabolism in critically ill patients : The SPN2 randomized tracer study. Clin Nutr 38 : 2408-2416, 2019

15) Allingstrup MJ, Kondrup J, Wiis J et al. : Early goal-directed nutrition versus standard of care in adult intensive care patients : the single-centre, randomised, outcome assessor-blinded EAT-ICU trial. Intensive Care Med $43: 1637-1647,2017$

16) Thiessen SE, Derde S, Derese I et al. : Role of Glucagon in Catabolism and Muscle Wasting of Critical Illness and Modulation by Nutrition. Am J Respir Crit Care Med 196 : 1131-1343, 2017

17) Gunst J, Vanhorebeek I, Thiessen SE et al. : Amino acid supplements in critically ill patients. Pharmacological research 130 : 127-131, 2018

18）大島 拓, 今井正太郎, 古川誠一郎ほか：PICS 対策と しての理学療法: 早期理学療法導入と挑戦. ICU と CCU 43 : 397-402, 2019

19）佐藤由美，大島 拓，柄澤智史ほか：【救急のチーム ワークとヒヤリハット】栄養療法プロトコールとチー 么医療. 日本腹部救急医学会雑誌 $38: 509-515,2018$

\title{
Early Nutrition and Mobilization for the Prevention of ICU-Acquired Weakness
}

\begin{abstract}
Taku Oshima $^{1)}$, Misako Haruyama ${ }^{2)}$, Shotarou Imai ${ }^{3)}$, Seiichirou Furukawa ${ }^{3)}$, Yumi Sato ${ }^{4)}$
ICU-acquired weakness (ICU-AW) has drawn greater attention due to its increased incidence as a result of the recent increase in survival of critically ill patients. Early mobilization and nutrition have been suggested to prevent ICU-AW. We introduced a multi-disciplinary team to promote early mobilization and nutrition. Mobilization is started early according to the maximum tolerable physical load for each patient. Nutrition is administered to fulfill a predefined target for both energy and protein in the early phase for each patient. According to our retrospective investigation, patients with early sufficient provision of protein are more likely to preserve muscle mass. Future studies to elucidate the optimal timing and methods to implement mobilization and nutrition for ICU-AW prophylaxis are needed.
\end{abstract}

ICU-AW, Early nutrition therapy, Protein nutrition, Early physiotherapy, Multi-disciplinary approach

Emergency and Critical Care Medicine, Chiba University Graduate School of Medicine ${ }^{1}$

1-8-1 Inohana, Chuo-ku, Chiba City, Chiba 260-8677, JAPAN

Intensive Care and Cardiac Care Unit, Chiba University Hospital ${ }^{2)}$

Department of Rehabilitation, Chiba University Hospital ${ }^{3}$

Department of Clinical Nutrition, Chiba University Hospital ${ }^{4)}$ 